\title{
Psychiatry of whiplash neck injury ${ }^{\dagger}$
}

\author{
RICHARD MAYOU and BRIDGET BRYANT
}

\section{Background The psychiatric outcome of whiplash neck injury is controversial.}

\begin{abstract}
Aims To describe outcomes and predictors as compared with other types of road accident injury.
\end{abstract}

\section{Method Consecutive emergency} department attenders ( $n=1148$; whiplash 278) assessed by self-report at baseline, 3 months, I year and 3 years.

Results Moderate to severe pain was reported by $27 \%$ of whiplash sufferers at I year and by $30 \%$ at 3 years. Psychiatric consequences were common and persistent. Whiplash victims and those with bony injury were more likely to seek compensation. Accident and early postaccident psychosocial variables predicted the pain at I year. Claiming compensation at 3 months predicted the pain at I year for those with whiplash or bony injury.

Conclusions There is no special psychiatry of whiplash neck injury. Psychological variables and consequences are important following whiplash in a similar manner to other types of injury.

Declaration of interest None.
Whiplash neck injury is the most common type of injury following a road traffic accident (Spitzer et al, 1995) and claims for persistent symptoms make up $85 \%$ of all motor accident personal injury claims in the UK. There has been long-standing acrimony about whether complaints are attributable to physical pathology or to psychological mechanisms such as deliberate exaggeration and simulation. We use data from a 1-year consecutive series of all attenders at a hospital emergency department following a road accident (Mayou et al, 2001) in order to consider two questions:

(a) What are the physical, psychological and social consequences of whiplash neck injury and other types of injury in road accidents?

(b) Do psychological and social factors that can be assessed at the time of injury or at 3-month follow-up predict pain and psychiatric outcomes at 1 year for whiplash victims and are the predictors different from those for other types of injury?

\section{METHOD}

Consecutive patients $(n=1441)$ aged 17-69 years who attended the Accident and Emergency Department of the John Radcliffe Hospital, Oxford, following a road traffic accident (vehicle occupants, motorcyclists, cyclists, pedestrians) over a 1-year period were approached to take part in the study.

Those with head injury who had been unconscious for more than $15 \mathrm{~min}$ were excluded. Information from the ambulance and emergency department notes was coded by the research nurse, who categorised them into three injury types: no injury, soft-tissue injury only and bony injury. The soft-tissue injury group was divided into those with whiplash injury, defined as a diagnosis of whiplash or any mention of neck pain or discomfort, and those with all other soft-tissue injury. At a later stage this classification was checked by another member of the research team in collaboration with an emergency medicine specialist, and the injury severity score (ISS) of the Abbreviated Injury Scale (American Association for Automotive Medicine, 1990) was calculated. The ISS is a score comprising the sum of the squares of the three worst injury scores in up to three different body areas.

One set of medical records was missing. Of the remaining 1440, 337 (23\%) were identified as having a whiplash injury, 570 $(40 \%)$ as other soft-tissue injury, 247 $(17 \%)$ as bony injury and $286(20 \%)$ as no injury. In the 'whiplash' group the great majority $(81 \%)$ had no other injury and an ISS score of unity, but one-fifth had other minor soft-tissue injuries. In the 'other soft-tissue' group nearly all (97\%) had only minor lacerations or abrasions and ISS scores of $\leqslant 3$. The 'bony injury' group had a median ISS score of 4 (range 1-25).

Data were collected in the emergency department or by immediate mailing using self-completion questionnaires. The baseline questionnaire covered details of family background, previous travel and road accident injury, trait worry and emotional problems in the previous month (Ehlers $e t$ al, 1998). A six-question version of the SF-36 Health Survey (Ware et al, 1992) was used to measure health problems and limitation of activities in the month before the accident. Respondents also rated the accident in terms of how well they remembered it, how frightening they had found it (from 'very frightening' to 'not frightening') and whether they felt to blame. They also rated their emotional reactions to the accident on five-point rating scales from 'not at all' to 'extremely' on ten specified emotions; these included feeling angry, anxious, shaky, weepy, calm and dissociative symptoms (dazed and numb).

Follow-up questionnaires, which were sent at 3 months, 1 year and 3 years after the accident, covered physical recovery, further treatment, financial, work and legal problems, return to travelling and cognitions and cognitive strategies to deal with unpleasant memories of the accident. The health and activities questionnaire was repeated and participants completed the Post-Traumatic Stress Symptoms (PSS) scale (Foa et al, 1993) and the Hospital Anxiety and Depression (HAD) scale 
(Zigmond \& Snaith, 1983). The 3-year questionnaire was sent only to participants who had also completed either the 3-month or the 1-year questionnaire $(n=917)$.

\section{Cognitive maintaining factors}

The frequency of cognitions about memories of the accident was rated by respondents from 0 ('never') to 4 ('always'): 1 , rumination was the mean score of 'Why did it happen to me?' and 'I dwell on memories of the accident'; 2, thought suppression was the mean score of 'I try to push them out of my mind' and 'I try to distract myself'; 3, negative interpretations of intrusive recollections was the mean of 'I must be going out of my mind' and 'I will never get over it'; 4, anger cognition was the score on 'Others have harmed me'.

\section{Outcome variables}

\section{Physical}

Recovery. A three-point rating of 'back to normal', 'minor problems only' or 'major problems' in reply to the question 'How well have you recovered from your accident injuries?'.

Subjective pain. A six-point rating from 'none' to 'very severe' to the question 'How much bodily pain have you had generally during the last 4 weeks?'.

\section{Psychological}

Phobic travel anxiety. A measure based on previous research (Mayou \& Bryant, 1994) combining increased nervousness about travelling and avoidance with cutoff points consistent with the DSM-IV (American Psychiatric Association, 1994) criteria for phobia.

Anxiety case. The recommended anxiety cut-off of 10 or more on the HAD scale (Zigmond \& Snaith, 1983).

Depression case. The recommended HAD depression cut-off of 10 or more.

Post-traumatic stress disorder. The minimum number of symptoms on the PSS scale (Foa et al, 1993) required by DSM-IV criteria.
Social

Financial and work problem. Three-point ratings of 'no', 'yes, minor' or 'yes, major' to the questions 'Has the accident resulted in financial problems for you now?' and 'Has the accident caused problems for your work situation now (e.g. your ability to work/the sort of work you can do/lost job, etc.)?'.

Limitation in daily activities and limitation in social activities. Five-point ratings from 'not at all' to 'extremely' in reply to two questions on the health and daily activities questionnaire.

\section{RESULTS}

Of the 1441 attenders at the emergency clinic who were given the baseline questionnaire 1148 (80\%) completed it. Of these participants, $864(75 \%)$ completed the 3month follow-up and $772(67 \%)$ completed the 1-year follow-up. At 3 years, 538 (59\%) of the 917 who were sent a questionnaire completed it.

In the sample as a whole, men and younger people aged under 30 years were less likely to participate at baseline. Those with bony or whiplash injury were more likely to participate initially than others (89\% bony, $83 \%$ whiplash, $76 \%$ other soft tissue, $77 \%$ no injury; $\chi^{2}=21.46$, d.f. 3 , $P<0.001$ ).

\section{Non-participants and drop-outs}

There were no relationships between participation and vehicle type, driver status or previous road accident injury. Participants who remained in the study were compared with those who dropped out at later stages. Dropping out was not related to any of the health and psychological measures assessed at baseline. Those in manual occupations were less likely to remain in the study, and this was significant for the whiplash and other soft-tissue injury groups.

\section{Characteristics of the participants}

Characteristics of the participants are shown in Table 1 . Whiplash sufferers were no more likely than other groups to report previous psychological problems or to describe themselves as worriers.

\section{Immediate reactions to the accident}

Immediate reactions to the accident are shown in Table 2. Whiplash subjects were more likely than other accident victims to have found the accident frightening and to feel they were not to blame. The whiplash and uninjured subjects were more likely to have a clear memory of the accident. Whiplash subjects also rated themselves as feeling more weepy, anxious and angry and, together with the other soft-tissue injury group, as more shaky. Anger was more conspicuous in the whiplash group than in other groups, even when controlling for blame for the accident.

\section{Outcome}

Outcomes at 3 months, 1 year and 3 years are shown in Table 3.

\section{Psychological outcomes}

The patterns of psychological consequences at the 3 month and 1-year follow-ups were very similar in all the groups. About onethird had psychological complications at 1 year.

\section{Physical outcomes}

Recovery was worst for the bony injury group and best for the other soft-tissue and no injury groups, with the whiplash group intermediate. The picture was similar for those reporting continuous moderate to very severe pain, but at 3 years slightly more of the whiplash subjects than the bony injury subjects were reporting pain. Use of general practice consultation and physiotherapy also was similar in the whiplash and bony injury subjects; $48 \%$ in the whiplash group and $56 \%$ in the bony injury group reported treatment by a physiotherapist, osteopath or chiropractor in the first 3 months, compared with less than $15 \%$ with soft tissue or no injury.

\section{Social outcomes}

There were some differences in social consequences. The whiplash and bony injury groups were more likely throughout to report financial and work problems and limitation of daily activities than those with soft tissue or no injury. At three months those with bone injury also reported more limitation in their social life. 
Table I Characteristics of participants by type of injury $(n=\mid 147)^{\prime}$

\begin{tabular}{|c|c|c|c|c|c|}
\hline & $\begin{array}{l}\text { Whiplash injury } \\
\qquad(n=278)\end{array}$ & $\begin{array}{l}\text { Other soft-tissue } \\
\text { injury }(n=43 \mathrm{I})\end{array}$ & $\begin{array}{c}\text { No injury } \\
(n=219)\end{array}$ & $\begin{array}{c}\text { Bony injury } \\
(n=219)\end{array}$ & $P$ value $^{2}$ \\
\hline \multicolumn{6}{|l|}{ Demographic } \\
\hline \multicolumn{6}{|l|}{ Age (years) } \\
\hline Mean & 32.67 & 32.20 & 30.16 & 36.63 & $<0.001$ \\
\hline s.d. & 11.75 & 13.53 & 12.00 & 14.12 & \\
\hline \multicolumn{6}{|l|}{ Gender $(n, \%)$} \\
\hline Male & $108(39)$ & $241(56)$ & $125(57)$ & $156(71)$ & $<0.001$ \\
\hline Female & $170(61)$ & $190(44)$ & $94(43)$ & $63(29)$ & \\
\hline \multicolumn{6}{|c|}{ Social class ( $n, \%)$} \\
\hline Non-manual & 171 (7I) & $193(59)$ & $104(64)$ & $99(54)$ & $<0.01$ \\
\hline Manual & 71 (29) & $136(41)$ & $59(36)$ & $86(47)$ & \\
\hline Not known & 36 & 102 & 56 & 34 & \\
\hline \multicolumn{6}{|l|}{ Accident } \\
\hline \multicolumn{6}{|c|}{ Road user group ( $n, \%)$} \\
\hline Driver & $193(69)$ & $175(4 I)$ & I4I (64) & $91(42)$ & $<0.001$ \\
\hline Passenger & $78(28)$ & $75(17)$ & $54(25)$ & $32(15)$ & \\
\hline Motorcyclist & $3(I)$ & $62(14)$ & $13(6)$ & $57(26)$ & \\
\hline Cyclist & $4(I)$ & $86(20)$ & $7(3)$ & $26(12)$ & \\
\hline Pedestrian & - & $33(8)$ & $4(2)$ & $13(6)$ & \\
\hline \multicolumn{6}{|c|}{$\begin{array}{l}\text { Previous road traffic } \\
\text { accident injury }(n, \%)\end{array}$} \\
\hline Yes & $82(30)$ & $124(29)$ & $58(27)$ & $79(36)$ & NS \\
\hline No & $194(70)$ & $306(7 I)$ & $158(73)$ & $140(64)$ & \\
\hline Not known & 2 & 1 & 3 & & \\
\hline \multicolumn{6}{|c|}{ Psychological vulnerability } \\
\hline \multicolumn{6}{|c|}{$\begin{array}{l}\text { Emotional problems in } \\
\text { previous } 6 \text { months ( } n, \%)\end{array}$} \\
\hline Yes & $56(20)$ & $92(22)$ & $46(2 I)$ & $48(22)$ & NS \\
\hline No & $222(80)$ & $334(78)$ & $173(79)$ & $170(78)$ & \\
\hline Not known & - & 5 & - & 1 & \\
\hline \multicolumn{6}{|c|}{ Trait worry $(n, \%)$} \\
\hline $3+$ & $37(13)$ & $40(9)$ & $21(10)$ & $31(14)$ & NS \\
\hline$<3$ & $240(87)$ & $384(91)$ & $198(90)$ & $186(86)$ & \\
\hline Not known & I & 7 & & 2 & \\
\hline
\end{tabular}

I. Hospital records were missing for one person.

2. Test of significance for age was analysis of variance: $F=9.73$, d.f. $=3,1143$; for other variables it was $\chi^{2}$, d.f. $=3$; for road user group, d.f. $=12$.

\section{Compensation}

The whiplash and bony injury groups were significantly more likely to claim compensation than the other two groups. These differences remained significant after controlling for blame. Among those feeling not to blame, $71 \%$ of those with whiplash and bony injury made claims compared with $53 \%$ of those with other soft-tissue injury and $42 \%$ of those not injured $\left(\chi^{2}=28.6\right.$, d.f. $\left.3, P<0.001\right)$. Thirty per cent of claims made by whiplash sufferers had models. These were gender, prior emotional problems, negative emotion, injury severity (bony injury group only), perceived threat, blame, initial emotional distress, four cognitive maintaining factors and claiming compensation at 3 months.

\section{Predictors of any psychological consequences}

In the sample as a whole, significant predictors after adjustment for the effect of other variables were female gender, psychological vulnerability and 3-month cognitive factors of rumination, anger and negative interpretations of intrusive memories of the accident; these accounted for $21 \%$ of the deviance.

When predictor variables were entered singly, there were many similarities between the injury groups. For all four groups, emotional distress immediately after the accident and rumination, anger and negative interpretations at 3 months were significant. For the whiplash, other soft-tissue and no injury groups, psychological vulnerability and perceived threat were significant. After adjustment, psychological vulnerability and negative interpretations remained significant predictors for the other soft-tissue and no injury groups. In the whiplash group the only predictor variable to remain significant was rumination. In the bony injury group there were no variables significant at the 0.005 level (Bonferroni correction). Claiming compensation was not significant after adjustment for any of the groups.

\section{Predictors of pain at I year}

Subjective pain at 1 year was used as the main physical outcome variable. The results are shown in Table 4 . When variables were entered on their own, feeling not to blame for the accident and claiming compensation at 3 months predicted pain at 1 year for those with whiplash and bony injury, and being a claimant predicted pain at 1 year for those with other soft-tissue injury. Initial anger or anger cognitions at 3 months were significant predictors for all the groups except the bony injury group. In the other soft-tissue group initial high emotional distress and all the cognitive maintaining factors predicted outcome. Pre-accident emotional state was not a significant predictor except for those in the no injury group.

After adjustment for the effects of the other variables, only claiming compensation at 3 months remained significant 
Table 2 Reactions to the accident of participants by type of injury $(n=1147)^{\prime}$

\begin{tabular}{|c|c|c|c|c|c|c|c|c|c|}
\hline & \multicolumn{2}{|c|}{ Whiplash injury } & \multicolumn{2}{|c|}{ Other soft-tissue injury } & \multicolumn{2}{|c|}{ No injury } & \multicolumn{2}{|c|}{ Bony injury } & \multirow[t]{2}{*}{$P$ value $^{2}$} \\
\hline & $n$ & (\%) & $n$ & (\%) & $n$ & (\%) & $n$ & (\%) & \\
\hline \multicolumn{10}{|l|}{ Memory of accident } \\
\hline Clear & 217 & (79) & 282 & (66) & 155 & (72) & 143 & (65) & $<0.01$ \\
\hline Patchy & 53 & (19) & 119 & (28) & 55 & (26) & 59 & (27) & \\
\hline None & 6 & $(2)$ & 27 & (6) & 6 & (3) & 17 & (8) & \\
\hline Not known & 2 & & 3 & & 3 & & & & \\
\hline \multicolumn{10}{|l|}{ Blames self for accident } \\
\hline No & 231 & (83) & 281 & (66) & 158 & (73) & 137 & (63) & $<0.001$ \\
\hline Partly & 21 & (7) & 86 & (20) & 32 & (15) & 44 & (20) & \\
\hline Yes & 25 & (9) & 60 & (14) & 27 & (12) & 35 & (16) & \\
\hline Not known & 1 & & 4 & & 2 & & 3 & & \\
\hline \multicolumn{10}{|l|}{ Accident frightening } \\
\hline Moderate-very & 199 & (72) & 283 & (66) & 142 & (66) & 123 & (56) & $<0.01$ \\
\hline No-slight & 77 & $(28)$ & 147 & (34) & 74 & (34) & 123 & (56) & \\
\hline Not known & 2 & & I & & 3 & & & & \\
\hline \multicolumn{10}{|l|}{ Emotions } \\
\hline \multicolumn{10}{|l|}{ Angry } \\
\hline Moderate-extreme & 126 & (46) & 150 & (35) & 71 & (33) & 61 & (28) & 0.001 \\
\hline None-slight & 150 & (54) & 276 & (65) & 144 & (67) & 157 & (72) & \\
\hline Not known & 2 & & 5 & & 4 & & 1 & & \\
\hline \multicolumn{10}{|l|}{ Anxious } \\
\hline Moderate-extreme & 127 & (46) & 154 & (36) & 74 & (35) & 84 & (39) & $<0.05$ \\
\hline None-slight & 147 & (54) & 271 & (64) & 140 & (65) & $|3|$ & (61) & \\
\hline Not known & 4 & & 6 & & 5 & & 4 & & \\
\hline \multicolumn{10}{|l|}{ Dazed } \\
\hline Moderate-extreme & 44 & (16) & 86 & (20) & 36 & (I7) & 29 & (14) & NS \\
\hline None-slight & 230 & (84) & 338 & (80) & 178 & (83) & 186 & (87) & \\
\hline Not known & 4 & & 7 & & 5 & & 4 & & \\
\hline \multicolumn{10}{|l|}{ Shaky } \\
\hline Moderate-extreme & 93 & (34) & 159 & (37) & 62 & (29) & 54 & (25) & $<0.01$ \\
\hline None-slight & 181 & (66) & 268 & (63) & 155 & (7) & 162 & (75) & \\
\hline Not known & 4 & & 4 & & 2 & & 3 & & \\
\hline \multicolumn{10}{|l|}{ Weepy } \\
\hline Moderate-extreme & 78 & (29) & 84 & (20) & 50 & (23) & 32 & (15) & $<0.01$ \\
\hline None-slight & 196 & (72) & 341 & (80) & 166 & (77) & 182 & (85) & \\
\hline Not known & 4 & & 6 & & 3 & & 5 & & \\
\hline
\end{tabular}

I. Hospital records were missing for one patient.

2. Test of significance was $\chi^{2}$, d.f. $=3$; for 'memory of accident' and 'blames self' groups, d.f. $=6$.

for those with whiplash and bony injury, with claimants being four times more likely to report pain at 1 year than nonclaimants. In the no injury group only gender remained significant; women in this group were ten times more likely to report pain at 1 year than men were. Severity of injury did not predict pain at 1 year, even in the bony injury group. The total amounts of deviance explained were modest.

\section{DISCUSSION}

Few studies have assessed the mental state outcome of whiplash injury and there has been little prospective research on psychological variables (Mayou \& Bryant, 1996; Mayou \& Radanov, 1996). This study has the major advantage that the whiplash subjects were part of a larger study of all road traffic accident consecutive emergency department attenders over a 1-year period (Ehlers et al, 1998), thereby enabling comparison with outcome following other types of injury. Limitations of the study are that assessment was by self-report, there were non-respondents at each stage and especially at 3 years, and the sample excluded victims who did not attend emergency departments. Validity of the self-report methodology is supported by 
Table 3 Outcomes $(n, \%)$ at 3 months, I year and 3 years by type of injury'

\begin{tabular}{|c|c|c|c|c|c|c|c|c|c|}
\hline & \multicolumn{2}{|c|}{ Whiplash injury } & \multicolumn{2}{|c|}{ Other soft-tissue injury } & \multicolumn{2}{|c|}{ No injury } & \multicolumn{2}{|c|}{ Bony injury } & $P$ value $^{2}$ \\
\hline$n$ at 3 months & \multicolumn{2}{|c|}{208} & \multicolumn{2}{|c|}{306} & \multicolumn{2}{|c|}{165} & \multicolumn{2}{|c|}{185} & \\
\hline$n$ at I year & \multicolumn{2}{|c|}{187} & \multicolumn{2}{|c|}{285} & \multicolumn{2}{|c|}{138} & \multicolumn{2}{|c|}{162} & \\
\hline$n$ at 3 years & \multicolumn{2}{|c|}{124} & \multicolumn{2}{|c|}{200} & & 92 & \multicolumn{2}{|c|}{122} & \\
\hline \multicolumn{10}{|c|}{ Health/treatment } \\
\hline \multicolumn{10}{|c|}{ Recovery: minor-major problem } \\
\hline 3 months & 132 & (64) & 136 & (44) & 53 & $(32)$ & 144 & (78) & $<0.001$ \\
\hline I year & 93 & (50) & 105 & (37) & 35 & $(25)$ & 113 & (70) & $<0.001$ \\
\hline 3 years & 55 & (44) & 56 & (28) & 20 & $(22)$ & 70 & (57) & $<0.001$ \\
\hline \multicolumn{10}{|c|}{ Bodily pain: moderate-severe-very severe } \\
\hline 3 months & 77 & (37) & 59 & (20) & 23 & $(14)$ & 79 & (43) & $<0.001$ \\
\hline I year & 50 & (27) & 56 & (20) & 19 & (14) & 46 & (29) & $<0.01$ \\
\hline 3 years & 37 & (30) & 29 & (I5) & 16 & $(17)$ & 30 & $(25)$ & $<0.001$ \\
\hline \multicolumn{10}{|c|}{ Seeing general practitioner } \\
\hline 3 months & 117 & (57) & $|4|$ & (46) & 47 & (29) & 116 & (63) & $<0.001$ \\
\hline I year & 28 & (15) & 36 & (13) & $\mathrm{II}$ & $(8)$ & 33 & (2I) & $<0.01$ \\
\hline 3 years & 16 & (13) & 11 & (6) & 7 & (8) & 14 & (12) & NS \\
\hline Out-patient no & & & & & & & & & \\
\hline 3 months & 27 & (13) & 24 & (8) & 3 & (2) & 87 & (47) & $<0.001$ \\
\hline I year & 10 & (5) & 12 & (4) & 0 & (0) & 37 & (24) & $<0.001$ \\
\hline 3 years & 6 & (5) & 3 & (2) & I & (I) & 9 & (7) & $<0.02$ \\
\hline Physiotherapy & & & & & & & & & \\
\hline 3 months & 82 & (40) & 41 & (13) & 14 & (9) & 101 & (55) & $<0.001$ \\
\hline I year & 25 & (14) & 13 & (5) & 3 & (2) & 18 & (12) & $<0.001$ \\
\hline 3 years & 15 & (12) & 7 & (4) & 3 & (3) & 9 & (7) & $<0.02$ \\
\hline Psychological & & & & & & & & & \\
\hline Post-traumatic & & & & & & & & & \\
\hline 3 months & 50 & (24) & 70 & (23) & 30 & (18) & 48 & (26) & NS \\
\hline I year & 28 & (15) & 52 & (18) & 15 & (II) & 33 & (2I) & NS \\
\hline 3 years & 21 & (17) & 15 & (7) & 9 & $(10)$ & 15 & (12) & NS \\
\hline HAD anxiety & & & & & & & & & \\
\hline 3 months & 43 & (2I) & 54 & (18) & 28 & (17) & 33 & (18) & NS \\
\hline I year & 48 & (25) & 58 & (2I) & 22 & (16) & 27 & (17) & NS \\
\hline 3 years & 29 & (24) & 27 & (14) & 17 & (19) & 21 & (17) & NS \\
\hline Phobic travel a & & & & & & & & & \\
\hline 3 months & 43 & (2I) & 66 & (22) & 31 & (19) & 45 & (25) & NS \\
\hline I year & 29 & (16) & 45 & (16) & 22 & (16) & 31 & (19) & NS \\
\hline 3 years & 23 & (19) & 26 & (13) & 9 & (10) & 17 & (14) & NS \\
\hline Any psycholog & & & & & & & & & \\
\hline 3 months & 78 & (37) & 198 & (36) & 50 & (30) & 71 & (39) & NS \\
\hline I year & 65 & (35) & 89 & (3I) & 37 & (28) & 57 & (35) & NS \\
\hline 3 years & 38 & (35) & 41 & (23) & 63 & (18) & 41 & (37) & $<0.01$ \\
\hline Social & & & & & & & & & \\
\hline Financial probe & & & & & & & & & \\
\hline 3 months & 98 & (47) & 108 & (36) & 57 & (35) & 98 & (52) & $<0.001$ \\
\hline I year & 62 & (34) & 59 & (2I) & 23 & (17) & 61 & (38) & $<0.001$ \\
\hline 3 years & 20 & (16) & 15 & (8) & 6 & (7) & 23 & (19) & $<0.02$ \\
\hline Work problem & & & & & & & & & \\
\hline 3 months & & & & Not a & able & & & & \\
\hline I year & 46 & (25) & 47 & (I7) & 20 & (15) & 60 & (38) & $<0.001$ \\
\hline 3 years & 28 & (23) & 24 & (12) & 10 & (II) & 32 & (26) & 0.02 \\
\hline
\end{tabular}


Table 3 (continued)

\begin{tabular}{|c|c|c|c|c|c|}
\hline & Whiplash injury & Other soft-tissue injury & No injury & Bony injury & $P$ value $^{2}$ \\
\hline \multicolumn{6}{|c|}{ Daily activities limited in previous 4 weeks: moderate-extremely } \\
\hline 3 months & 32 (15) & (9) & (4) & $59 \quad(32)$ & $<0.001$ \\
\hline I year & $21 \quad(\mathrm{II})$ & (8) & (5) & $26 \quad(16)$ & $<0.01$ \\
\hline 3 years & $19 \quad(15)$ & (5) & (5) & $18 \quad(15)$ & $<0.01$ \\
\hline \multicolumn{6}{|l|}{ Legal } \\
\hline \multicolumn{6}{|c|}{ Claiming compensation } \\
\hline 3 months & $128 \quad(62)$ & $115 \quad(38)$ & $55 \quad(34)$ & $94 \quad(5 I)$ & $<0.001$ \\
\hline I year & III (60) & $103 \quad(37)$ & $43 \quad(3 I)$ & $83 \quad(52)$ & $<0.001$ \\
\hline 3 years & $67 \quad(54)$ & $72 \quad(36)$ & $32 \quad(35)$ & $53 \quad(42)$ & $<0.01$ \\
\hline \multicolumn{6}{|l|}{ Claim settled } \\
\hline 3 months & - & - & - & - & \\
\hline I year $(n=340)$ & $33 \quad(30)$ & $31 \quad(30)$ & $13 \quad(30)$ & $7 \quad(8)$ & $<0.05$ \\
\hline 3 years $(n=224)$ & $50 \quad(75)$ & $63 \quad(88)$ & $26 \quad(8 I)$ & $30 \quad(57)$ & $<0.001$ \\
\hline
\end{tabular}

I. Numbers and percentages are shown for only one category of the dichotomous variables.

2. Test of significance: $\chi^{2}$, d.f. $=3$.

HAD, Hospital Anxiety and Depression scale.

Table 4 Rate ratios of pain at I year, before and after adjustment for all other baseline and 3-month factors, by injury group

\begin{tabular}{|c|c|c|c|}
\hline \multirow[t]{2}{*}{ Factor } & \multicolumn{2}{|c|}{ Pain at I year' } & $95 \% \mathrm{Cl}$ for adjusted rate ratio \\
\hline & Unadjusted rate ratio ${ }^{2}$ & Adjusted rate ratio ${ }^{2}$ & \\
\hline
\end{tabular}

Whiplash $(n=156)$

\section{Baseline}

Blames self (no)

Anger (high)

3 months

Claimant (yes)

Anger cognition (high)

Deviance explained: $9.69 \%$

Other soft-tissue injury $(n=232)$

$\begin{array}{lll}\text { Baseline } & \text { Frightening (very) } & 2.32^{*} \\ \text { 3 months } & \text { Negative emotion (high) } & 2.81^{* *} \\ & \text { Negative interpretation (high) } & 3.38^{* *} \\ & \text { Claimant (yes) } & 2.33^{*} \\ & \text { Rumination (high) } & 2.37^{*} \\ & \text { Thought suppression (high) } & 2.31^{*} \\ & \text { Anger cognition (high) } & 2.42^{*}\end{array}$

Deviance explained: $7.50 \%$

No injury $(n=119)$

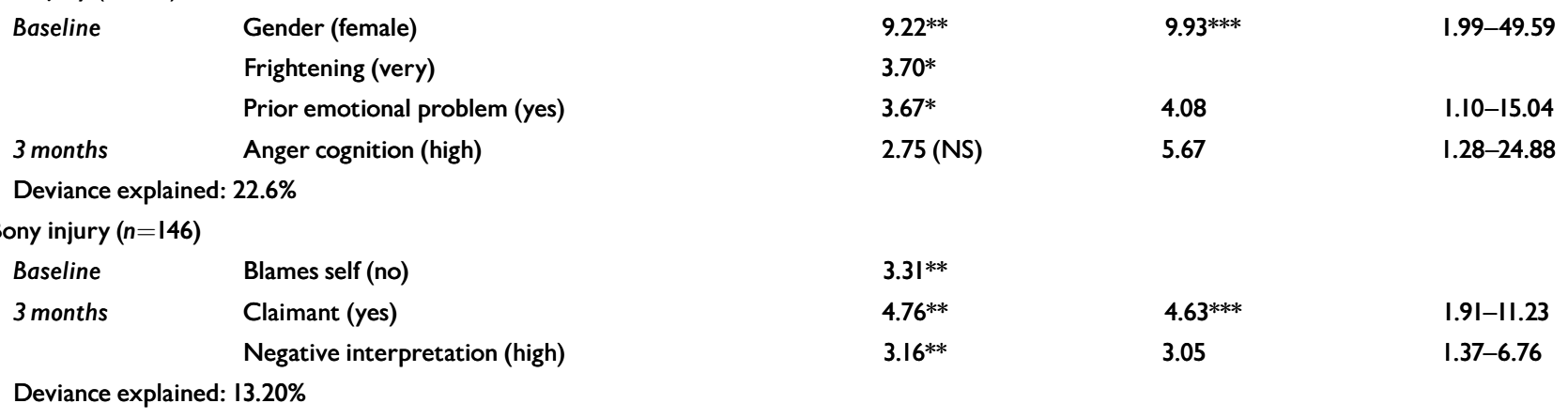

I. The dichotomous dependent variable is the logit of the probability of moderate to very severe pain at I year.

2. Each rate ratio is compared with a reference category that has the value 1.00 . For each dichotomous factor the reference category (not shown) is the remainder, with presence/ absence or high/low score as appropriate.

$* P<0.05, * * P<0.01, * * * P<0.0042$ compared with reference category (Bonferroni correction 0.05/12).
$3.70 *$

2.14*

$4.8 I^{* *}$

4.27***

|.6-II.I

I.0-4.8
$2.32 *$

$38 * *$

2.25

I.07-4.74

2.90***

|.4|-5.96

$31 *$

$42 *$

$3.3 I^{* *}$ 
the similarity of findings with our previous interview study (Mayou et al, 1993) and an interviewed sub-sample (details available from the author upon request), both of which had high response rates.

\section{What are the physical, psychological and social consequences of whiplash neck injury and other types of injury in road accidents?}

Whiplash sufferers differ from those with no injury and those with other soft-tissue injury in that they report more pain and use of health care and more effects on finances, work and leisure activities, and in these respects their outcome resembles the outcome for those with bony injury. However, the psychiatric complications were similar for whiplash and other injuries. Apart from the higher frequency of post-traumatic stress disorder in this study (which can be attributed to the choice of a standard instrument that enabled DSM-IV diagnosis), they were also similar to those that we have described for whiplash victims in an earlier prospective study (Mayou \& Bryant, 1996).

\section{Do psychological and social factors that can be assessed at the time of the injury or at 3-month follow- up predict pain and psychiatric outcomes at I year for whiplash victims and are the predictors different from those for other types of injury?}

There were a number of factors that predicted psychological outcome in the sample as a whole, with few major differences between the injury categories. As in our previous study (Mayou et al, 1993), evidence of previous psychological vulnerability predicted the outcome of whiplash neck injury. Claiming compensation was not a predictor of psychological outcome in any of the injury groups.

Physical outcome was not predicted by measures of pre-accident psychological status and the principal predictors were variables relating to the accident itself, initial psychological response, subsequent cognitions and claiming compensation. It was notable that, even in those who had suffered fracture, injury severity did not contribute to the regression.

\section{CLINICAL IMPLICATIONS}

- Psychiatric consequences (post-traumatic stress disorder, travel anxiety, anxiety, depression) are common but their prevalence, course and treatment needs are very similar to those following other types of injury.

- Accident-associated and post-accident psychosocial variables are predictors of severity of pain at I year.

- Whiplash victims are especially likely to seek compensation but this reflects the high proportion of innocent victims, the physical symptoms and the ease of legal definition.

\section{LIMITATIONS}

- Physical information was based on clinical notes rather than research assessment.

Follow-up was by self-report.

Response rates decreased over the 3-year follow-up.

RICHARD MAYOU, FRCPsych, BRIDGET BRYANT, MSc, Oxford University Department of Psychiatry Warneford Hospital, Oxford

Correspondence: Richard Mayou,Warneford Hospital, Oxford OX3 7JX, UK. Tel: 01865226477

(First received 28 November 2000, final revision I June 200I, accepted 8 June 200I)

\section{Is there a psychiatry of whiplash?}

The findings show that there is no special psychiatry of whiplash. Psychiatric outcomes are entirely comparable to those following other types of road traffic accident. Predictors of pain generally are very similar to those identified after other types of injury.

Most writers on whiplash have considered physical and psychological explanations of physical symptoms as separate alternatives. This is incorrect; they are interacting, with both physical and psychiatric factors contributing to the overall impairment of the quality of everyday life. It is to be expected that the psychological consequences may influence perception of physical symptoms and that physical symptoms may maintain psychological problems. Behavioural reactions may have effects on posture and movement, with substantial effects on the course of recovery; anxiety and depression will affect the perception of physical symptoms; inconsistent or over-cautious medical advice is likely to exacerbate problems; slow, bewildering and apparently unsympathetic legal processes may perpetuate difficulties. Our findings demonstrate that these issues are important for the outcome of all types of road accident injury, not whiplash alone. Indeed, these conclusions are fully consistent with wider literature on back and other chronic pain (Linton, 1998, 2000) and medically unexplained symptoms (Mayou et al, 1995).

\section{The significance of compensation}

There are several reasons why whiplash neck injury is so prominent a cause of compensation claims. It is the most common type of road traffic accident injury $(24 \%$ of this series) and, compared with other injury categories, it is much more likely that the sufferer is an innocent victim and that the liability of the other driver will not be disputed. The proportion of victims who claim compensation is higher than for innocent victims with either no injury or other soft-tissue injuries (mainly abrasions, bruises and lacerations). It is similar to the proportion of claimants among those with bony injuries and this perhaps reflects the unpleasantness of the acute symptoms and 
the significant limitations of valued everyday activities associated with continuing whiplash symptoms.

The influence of compensation on course and outcome is complex, partly because proceedings are more likely, and also more likely to be prolonged, in those with the most distressing physical symptoms. Our findings are consistent with our 6-year follow-up of claimants (Bryant et al, 1997). We believe that the practical difficulties, the anger associated with being an innocent victim and the slowly progressing litigation mean that it is one of several social variables influencing overall quality of life following the accident. It is probable that post-traumatic stress disorder and other psychiatric complications are maintained by psychological variables such as reminders of the accident, continuing physical problems, further accidents and disability (Ehlers et al, 1998; Ehlers \& Clarke, 2000), and that seeking compensation acts in a similar manner in relation to pain.

\section{Implications}

An understanding of the multi-causal aetiology of the consequences of trauma, especially post-accident variables, leads to conclusions about more effective management:

(a) Immediate physical care should be clear and positive, provide acute symptomatic relief and encourage rapid and progressive mobilisation (Aker et al, 1996). (b) Persistent pain and psychological complications should be recognised early and access to specialist cognitivebehavioural and psychiatric treatment is essential.

(c) New approaches to medical care are only part of the solution; social and legal procedures also are important.

Better clinical understanding of psychological and behavioural issues would have benefits for patients and also could be expected to reduce the demands on medical resources. It would further enable changes in legal and compensation proceedings that would minimise their role in exacerbating the subjective severity of pain and other physical symptoms.

\section{REFERENCES}

Aker, P. D., Gross, A. R., Goldsmith, C. H., et al (1996) Conservative management of mechanical neck pain: systematic overview and meta-analysis. BM], $3 \mathbf{3} 3$ 129|-1296.

American Association for Automotive Medicine (1990) The Abbreviated Injury Scale. Des Plaines, IL: American Association for Automotive Medicine.

American Psychiatric Association (1994) Diagnostic and Statistical Manual of Mental Disorders (4th edn) (DSM-IV). Washington, DC: APA.

\section{Bryant, B., Mayou, R. \& Lloyd-Bostock, S. (1997)} Compensation claims following road accidents: a sixyear follow-up study. Medicine, Science and the Law, 37, 326-336.

Ehlers, A., Mayou, R. A. \& Bryant, B. (1998)

Psychological predictors of chronic posttraumatic stress disorder after motor vehicle accidents. Journal of Abnormal Psychology, 107, 508-519.
_ \& Clarke, D. M. (2000) A cognitive model of posttraumatic stress disorder. Behaviour Research and Therapy, 38, 319-345.

Foa, E. B., Riggs, D. S., Dancu, C. V., et al (1993)

Reliability and validity of a brief instrument for assessing posttraumatic stress disorder. Journal of Traumatic Stress, 6, 459-473.

Linton, S. J. (1998) The socioeconomic impact of chronic back pain: is anyone benefiting? Pain, $\mathbf{7 5}$, 163-168.

- (2000) A review of psychological risk factors in back and neck pain. Spine, 25, I148-1154.

Mayou, R., Bryant, B. \& Duthie, R. (1993) Psychiatric consequences of road traffic accidents. BM/, $\mathbf{3 0 7}$, 647-65I.

— \& - (1994) Effects of road accidents on travel. Injury, 25, 457-460.

_, Bass, C. \& Sharpe, M. (1995) Treatment of Functional Somatic Symptoms. Oxford: Oxford University Press.

— \& Bryant, B. (1996) Outcome of 'whiplash' neck injury. Injury, 27, 617-623.

- \& Radanov, B. P. (1996) Whiplash neck injury. Journal of Psychosomatic Research, 40, 46I-474.

_ \& Bryant, B. (200I) Outcome in consecutive emergency department attenders following a road traffic accident. British Journal of Psychiatry, 179 528-534.

Spitzer, W. O., Skovron, M. L., Salmi, L. R., et al (1995) Scientific monograph of the Quebec Task Force on Whiplash-Associated Disorders: redefining 'whiplash' and its management. Spine, 20 (suppl. 8), IS-73S.

Ware, J. E., Nelson, E. C., Sherbourne, C. D., et al (1992) Preliminary tests of a 6 -item general health survey: a patient application. In Measuring Functioning and Well Being (eds A. L. Stewart \& J. E. Ware), pp. 291-303. Durham, NC: Duke University Press.

Zigmond, A. S. \& Snaith, R. P. (1983) The Hospital Anxiety and Depression scale. Acta Psychiatrica Scandinavica, 67, 361-370. 